\title{
The Reflection of Women in Two Great American Writer's Creative Works: F. Scott Fitzgerald and Ernest Hemingway
}

\author{
Shahla Sorkhabi Darzikola \\ Department of English, Payame Noor University, Iran; E-mail: sorkhabish@yahoo.com
}

Fahimeh Keshmiri

Farhangian University, Fatemeh Zahra Pardis, Isfahan, Iran

\author{
Doi:10.5901/mjss.2015.v6n6s2p179
}

\begin{abstract}
The literary of heritages of two great writers in 20th century, F. Scott Fitzgerald and Ernest Hemingway, include several topics that are derived from experiences that they had with women in their life. The first major women who influenced Fitzgerald and Hemingway's lives and works were their mother. About Fitzgerald, besides his mother, his wife Zelda and two other women, Ginevra King and Sheilah Graham, played a major role in his life and deeply influenced his fiction as sources of inspiration. Agnes Von Kurowsky as Hemingway's nurse, his four wives, Jane Mason, and Adriana Ivancich were the women who really had affected his life and creative works besides his mother as sources of inspiration. The other women who seriously influenced both of them, was Gertrude Stein.
\end{abstract}

Keywords: Hemingway- Fitzgerald- women- wives- sources of inspiration- American writer

\section{Introduction}

The role of women in society is continually questioned and for centuries women have struggled to find their place in a world that is mostly male oriented. Literature provides the reader a window into the lives, actions, and thoughts of women. In the 19th century, women in literature were frequently portrayed as obedient to men. Literature of this time often characterized women as subjugated by society, as well as by the male influences in their lives. This era is particularly captivating because it is a time in modern society when women were still treated as second-class populace.

F.Scott Fitzgerald portrayed women in his several stories like The Great Gatsby and Tender Is the Night, Winter Dreams and Babes in the Woods. Ernest Hemingway depicted women in his some works such as The Short Happy Life of Francis Macomber, The Old Man and The Sea, Farewell to Arms and The Snows of Kilimanjaro.

\section{Literature Review}

One of the literary sources related to the topic of this paper is The Cambridge Companion to F. Scott Fitzgerald; the editor is Ruth Prigozy, Cambridge university press, 2002. "This particular volume has a great amount of information both in terms of analysis of Fitzgerald's works, and the ramifications their receptions had on Fitzgerald himself and on his careered. It takes note of Fitzgerald's career in terms of both his writing and his life, and presents the reader with a full and accessible picture of each, against the background of American social and cultural change in the early decades of the twentieth century" (Prigozy Ruth. 2002).

The next related book is the The Far Side of Paradise, a biography of F. Scott Fitzgerald by Arthur Mizener and a new introduction by Mathew J. Bruccoli, 2006. In the book Mizener mentioned that "there are three concentric areas of interest in a study of Scott Fitzgerald. At the heart of it is his work, for he was a natural writer if only in the sense that from his grade-school days until the end of his life nothing was ever quite real to him until he had written about it. Zelda is the second area of interest for a study of him, only less absorbing than the first, and, because his imagination worked so immediately from his experience, very related to it. The third area of interest is the time and place in which he lived" (Mizener Arthur. 1965).

Another related book written by Linda Wagner Martin is Ernest Hemingway: A Literary Life. New York. 2007. "In this book there is a wealth of information of Hemingway's life and works especially about his love of animals, natural 
world and his character. She explores Hemingway's friendship with women, several marriages, wars and his entertainment" (Martin Linda, W. 2007).

Another source that includes scientific information is Ernest Hemingway, University of Minnesota Press, by Young Philip, 1973. Philip Young in the book referred to: "...a brief description of biography of the Hemingway, his style, his hero, that is to say the protagonists of many of his works, who so resemble each other that we have come to speak of them in the singular, his manner and attitudes have been very widely recognized not just in the English-speaking world but wherever books are widely read" (Young Philip, 1973).

\section{Research Methodology}

As a first step, the researcher read books and papers that present the major issues and concerned of in theme of women. In the second step, the researcher read biographical work on Ernest Hemingway and F. Scott Fitzgerald's life to get a clear picture of their background, their development as writers and their response to the age that they lived in. The researcher, in the third step, did an exhaustive reading of Hemingway and Fitzgerald's major short stories and novels. As the last step the researcher studied critical works that analyses and reflect the thematic, philosophical, social, cultural and intellectual preoccupations that were revealed in Hemingway and Fitzgerald's life and works. In accomplishing this study, intrinsic approach and also apply descriptive analytical methods are used which combine with interpretation.

\section{Results and Discussion}

\subsection{Influential Women in Fitzgerald's Creative Works}

Mary (Mollie) McQuillan, F.Scott Fitzgerald's mother, was the first major woman who influenced his life. Fitzgerald's mother was a rich woman and while the Fitzgeralds fell into financial difficulty, they had to count on her. When they had this kind of problems "Mollie abandoned the attempt to keep up her personal appearance (neglecting both grooming and fashion), which embarrassed her fastidious son. Scott later recorded a dream in which he admitted being ashamed of her" (Essay on The Women Who Influenced Francis Scott Key Fitzgerald's life, 1969).

In Fitzgerald's childhood his mother was outstandingly unconventional in dress and manner that causing him some suffering. Mollie's family provided hold for the family during the author's childhood and they could live close to all of the affluent St. Paul families, and could not help but notice the manor belonging to railroad tycoon, James J. Hill, in walking distance from his own modest home. He wrote that "he felt like an outsider throughout his childhood, for although he lived among them and socialized with them; the rich inhabited a different world" (Scott Fitzgerald and Zelda Fitzgerald, 1981). That idea would find its way into his fiction - notably The Great Gatsby and Tender Is the Night.

Fitzgerald's feelings to his mother influenced him as an individual. Since before Scott's birth his two siblings had died, his mother was anxious about his physical condition. Fitzgerald reminded his mother's nervousness regarding his health all through his babyhood. But her efforts to ruin him strengthened his aversion for her. Mary desired her son to have social ambition. This aspiration to have a high social status and be a manager influenced Scott's personality and reflected in the most heroes of his fiction.

The second woman who influenced Fitzgerald was Ginevra King .Fitzgerald attended in prestigious Princeton University, but could not quite fit in because nearly all of the students were more affluent and came from more prosperous families than his own. In 1914, through a trip home to St. Paul, he met Ginevra King, at a dance. She was the core of whole thing Scott wanted and could not have. He pursued the relationship for over a year, but gave it up in 1916 after her father supposedly told Fitzgerald that "poor boys shouldn't think of marrying rich girls" (Bryant Mangum, 1981).

In 1918, Ginevra King married a man of her own social class and sent Fitzgerald a wedding announcement, which he saved. This first romance is reflected in most of his stories such as his first novel, The Romantic Egoist, which was named This Side of Paradise afterward. Ginevra King served as inspiration for the characters Isabelle, Rosalind, and Eleanor, the three very fashionable girls in the novel. Fitzgerald stated that "King dumped me with the most supreme boredom and indifference" (Noden Merrell, 2003). His failure to win Ginevra cut deep. The femme fatale, the wealthy and attractive woman always just idealistic, became a frequent theme in his works as well as his life.

About the role of Zelda Sayre, Fitzgerald's wife, as a source of inspiration it can be said when Fitzgerald was 23 years old and the First Lieutenant $67^{\text {th }}$ Infantry and aspiring writer he met the beautiful young Zelda Sayre at a Country Club dance in her hometown, Montgomery in July 1918. Several weeks later Scott seemed to have decided to marry Zelda, who in the end became, in effect, Scott's material. Almost all his books depicted variations on their life together, now and then incorporating bits of her diaries and letters as well. 
Zelda's family was Southern aristocracy. Undeniably, a Fitzgerald profile gets a combined profile of Scott and Zelda Fitzgerald. "She had the strongest influence on him after 1919, and the circumstances of their marriage formed his career. Without Zelda aside he might or might not have been a better caretaker of his genius; but it is folly to assign blame to either partner. They conspired in a hazardous game for which only they knew the rules" (Bruccoli Matthew Joseph, 2002). Zelda possessed a natural beauty and an attractive figure and her some features like - playful, often disobedient, rebellious and even uncontrolled and reckless distinguished her from other women. "She described herself as without a thought for anyone else... I did not have a single feeling of inferiority, or shyness, or doubt, and no moral principles" (The women in F. Scott Fitzgerald's life and fiction. http://Suite101.com/article/). She was without a doubt the ideal girl for Scott at that time, fervent for victory, a member of a famous (but not rich) family, self-governing, and beautiful. Her mother treated her with tender open-mindedness, allowing this youngest child the liberty she desired from her first years. She was disobedient, cheery, joyful, and even inconsiderate.

When Fitzgerald was working on The Great Gatsby, They lived for a short time on the French RivieraThrer. Zelda started an affair with Edouard Jozan, a French pilot When Fitzgerald was informed he became angry. Intensely distressed, Fitzgerald forced a quarrel with Jozan, who left. The whole episode endured six weeks. Such as Fitzgerald's control and severely imagined and felt was the material for his stories that these distressing events did not ruin his growth on the manuscript, called at diverse times Among The Ash Heaps and Millionaires, Trimalchio in West Egg, The Great Gatsby and Tender Is the Night. Zelda included elements of that event into Save Me the Waltz too. In Fitzgerald's notebooks, inscribed: "That September of 1924, I knew something had happened that could never be repaired" (Zelda Fitzgerald and the French Aviator. 2013).

About Zelda Hemingway described her as: "an insane and encouraged her husband to drink so as to distract Scott from his work on his novel" (Canterbery, 2006). But that time they were enjoying the fame that his novel, This Side of Paradise had brought. Their family life was topic to nonstop stress from their drinking, his desire about his work, her feelings of disregard, and their steady worry about enough profits.

"In January 1922, Scott wrote to the literary critic Edmund Wilson that, the complete, fine and full-hearted selfishness and chill-mindedness of Zelda enormously influenced his writing. Edmund Wilson agreed with Scott, saying, I have rarely known a woman who expressed herself so delightfully and so freshly; she had no ready-made phrases on the one hand and made no straining for effect on the other" (Alabama Women's Hall of Fame, 2012).

It can be said almost in all fictional heroines that Fitzgerald created Zelda was as a model. he said "I fell in love with her courage, her sincerity and her flaming self-respect and it's these things l'd believe in even if the whole world indulged in wild suspicions that she wasn't all that she should be... I love her and that's the beginning and the end of it" (Edmund Wilson, 1996). Fitzgerald inscribed, "Sometimes I don't know whether Zelda and I are real or whether we are characters in one of my novels" (Edmund Wilson, 1996).

The Beautiful and the Damned is considered his most autobiographical novel. Beautiful Gloria, who loves spending a good time and wants to marry a rich man, is the reflection of both his earlier romance with Ginevra and his wife, Zelda. Vain and self-centered Gloria is money-oriented, materialistic, and not interested in anything but her own selfish desires. Fitzgerald accepted the character Gloria was stimulated by his wife in both appearance and personality, but declared that Gloria was more shallow and vain than Zelda. Some overtones of Zelda can also be seen in the character of Daisy in The Great Gatsby. Tender is the Night the association between Dick and Nicole, a mental patient, is an obvious parallel to his marriage to the troubled Zelda. "She dreamt that his voice called to her, 'I have lost the woman I put in my book. Even when they were fighting a battle of wills, they were fighting more for each other than against each other" (Wagner Martin. Linda.2004). Another American writer, whose friendship with Fitzgerald and Hemingway should be mentioned, is, an American expatriate, Gertrude Stein "Stein herself had decided to experiment with the English language instead of writing common fiction. She practiced a kind of cubist writing which was based on rhythm, rhyme and repetition rather than on a sense making plot" (Ruland Richard and Bradbury Malcolm, 1991).

However, she gave useful advices to writers when required and was mentor for some of them. Included in this select crowd, was Scott Fitzgerald, for whose writing Stein always had a great admiration. Stein considered Fitzgerald as the most talented of American writers and delivered her declaration on The Great Gatsby: "Here we are and have read your book and it is a good book. I like the melody of your dedication it shows that you have a background of beauty and tenderness and that is a comfort. The next fine thing is that you write naturally in sentences and that too is a comfort. You write logically in sentences and one can read all of them and that among other things is a comfort. You are creating the modern world much as Thackeray did his in Pendants and Vanity Fair and this isn't a bad compliment. You make a modern world and a modern orgy strangely enough it was never done until you did it in This Side of Paradise. My belief in This Side of Paradise was alright. This is as good a book and different and older and that is what one does, one does not get better but different and older and that is always a pleasure" (Gertrude Stein's letter to F. Scott Fitzgerald). 
Though Fitzgerald was fascinated by Stein but he did not become an associate of her coterie. "He felt that Three Lives was a solid achievement, but that her later books were coo-coo. In The Autobiography of Alice B. Toklas, Stein wrote: Fitzgerald will be read when many of his well-known contemporaries are forgotten" (Gertrude Stein, 1961).

The last woman, who should be considered as the last source of inspiration for Fitzgerald was Sheilah Graham. When Fitzgerald accepted an offer to work for Metro-Goldwyn-Mayer Studios in Hollywood and moved to California. There he began an affair with British journalist Sheilah Graham, whom he met in a hotel on Sunset Boulevard called The Garden of Allah. At that time, the hotel was home to many famous writers and actors of the time. Sheilah Graham became Fitzgerald's companion for the rest of his life. At times their relationship was difficult because of his alcoholism. She was supportive of him and helped him quit drinking while he was working on his last novel, The Last Tycoon. Graham, who physically resembled Zelda, was the model for Kathleen Moore, who resembles Monroe Stahr's dead wife, Minna Davis, in Fitzgerald's uncompleted last novel.

Before the publication of The Great Gatsby, in 1924, Fitzgerald's family had moved to Paris to unite a growing community of American artists and writers drawn to France for its economic cost of living, great bars, liberal sexual systems, various presses and magazines eager to publish their works. Regardless of parties and the matrimonial trouble Fitzgerald produced an imposing amount of work all through (1925-1931)- forty-one stories, three novels, a play, and twenty-seven articles or reviews, as well as movie scenarios. This was the most creative stage of his life.

For some years F. Scott Fitzgerald was to serve as ambassador of literature to that Paris of the rich. He said of the 1920s: "America was going on the utmost, gaudiest spree in history and there was going to be plenty to tell about it. ... All the stories that came into my head had a touch of disaster in them - the lovely young creatures in my novels went to ruin, the Diamond Mountains of my short stories blew up .... " (Fitzgerald F. Scott, 1964).

\subsection{Influential Women in Hemingway's Creative Works}

Hemingway's mother, Grace Hemingway was an opera singer by training; she married a doctor with whom she was basically incompatible. Stuck it out more-or-less cheerfully, bearing six children. But she remained obdurate about the lifestyle she wanted which was a cosmopolitan Chicago lifestyle, filled with art and music. In the subsequent fantasy world of Ernest Hemingway's perpetually subservient female characters, this was a cardinal sin.

In Hemingway's childhood, his mother put on him like a girl, After he became six, she ended this behavior But it was late because the damage has already been done. John dos Passos, one of his best friends, said about Hemingway feeling to his mother. "From my earliest days with Ernest Hemingway, wrote Major General Charles T. Lanham about his friend Ernest Hemingway, he always referred to his mother as that bitch. He must have told me a thousand times how much he hated her and in how many ways. At other moments in his mature years Ernest spat out same invective. Grace Hemingway was a domineering shrew who drove her husband to suicide; she had a rule everything. John Passos said Ernest was the only man he ever knew who really hated his mother" (Kert Bernice, 1998).

Hemingway's nurse, Agnes Von Kurowsky Stanfield, was the second woman who influenced on him. She started to serve as a nurse in American Red Cross hospital in Milan during First World War. One of her patients was young Ernest Hemingway, who fell in love with her.

Ernest wanted to marry her but she was dedicated to her nursing career. Because of their age gap Agnes did not accept Hemingway's proposal.According to this event Hemingway inscribed Three Stories and Ten Poems. Even eleven years later Hemingway was still remembering his love affair with her and wrote A Farwell to Arms.

Other sources of inspiration for Hemingway were his wives. His first wife, Hadley Richardson married him in 1921 and upon the advice of "...Sherwood Anderson, American novelist and short story writer, they moved to Paris where they met other expatriate writers and artists including Ezra Pound, Gertrude Stein and F. Scott FitzGerald. When Hadley became pregnant, the couple decided to go to Toronto" (Baker Carlos, 1972). They made plan to watch the bullfighting in Pamplona, begins at midday on 6th July every year, for the first time. Such a life style and his accompany by Hedley, acted as the igniting fuel for the emergence of his under discussion novel.

In December 1922, Hadley packed Hemingway's manuscripts to take to Switzerland, where Hemingway was covering the Lausanne Peace Conference, but his fiction had been stolen and Hemingway had lost everything that he had written. After that incident "Gertrude Stein advised him to go to Spain; he would find new stories there. The Sun Also Rises is drawn from the Hemingway's real life experience with bullfighting in Spain, but Hadley was not in the book as a character although she was imperative to its making. In fact, without her financial and emotional support, Hemingway could not write this great novel. Next year Hadley and Hemingway got along by a group of American and British exile left Paris for visiting annual festival in Pamplona again" (Meyers Jeffrey, 1985).

During this journey he met Pauline Pfeiffer and this was the beginning ice for their marriage. Thereafter, his 
relationship with Hadley got worse and worse. Many critics favor this idea that this has been the starting point for a drastic alteration in his writing and the theme of his novel. After the journey, their marriage broke up when Hemingway was still writing it. One can see that the selection of the title that The Sun Also Rises refers to the way he has put an end to a life and has started a new one inspiring the critics and the readers to get courageous enough to take action for saving their life which at a macro level implicates the efforts of modern man for a better living after the depression.

The second of three St .Louis women who wed Hemingway was Pauline Pfeiffer. "A Farewell to Arms was output of the new life within this period. As one of Pauline became one of Ernest's only supporters in his plan to break his contract with Boni and Liveright. So Hemingway in only a few weeks during the autumn wrote a take-off on Anderson's recent novel. Both Gertrude Stein and John Dos Passos thought the work nasty and demeaning. Only Paulin Pfeiffer thought Hemingway's The Torrent of Spring brilliantly comic. In this first encounter between a non-supportive wife and chic woman who, though an outsider was herself a part of the literary world, Hemingway succumbed to Pauline's flattery" (Martin Linda Wagner, 2007).

A Farewell to Arms is written according to his second wife's difficult labor, Paulin Pfeiffer, and fighting on the Italian front. It implies some facts about his life and his attitude which can be deduced from this novel and the following novels under discussion. One can clearly come up with this idea that Hemingway as a war correspondent in Spain, during the years of his life with Pauline and according to the events of the Spanish Civil war, also wrote For Whom the Bell Tolls. But he certainly hated bullshit. And women exhale bullshit like men exhale carbon dioxide. From his domineering mother who made him wear pink gowns and flowered lace bonnets that matched his sister's to the World War I nurse who broke his heart she cured the yellowing of jaundice but caused the bluing of balls to the unsatisfactory spouses who drove him to other unsatisfactory spouses, the females in Papa's life each taught him a new lesson in disappointment.

The third wife of Ernest Hemingway, Martha Gellhorn was a novelist and journalist who were born in St. Louis, Missouri. Gellhorn and Hemingway had a Christmas family trip to Key West in 1936 and traveled to cover the Spanish civil war. "It was in Christmas 1936 when Hemingway first met war correspondent Martha Gellhorn at a bar in Key West, Florida. In 1937, Hemingway agreed to report on the Spanish Civil War for the North American Newspaper Alliance (NANA)" (Mellow James R. Hemingway, 1992).

"In March he arrived in Spain with Dutch filmmaker Joris Ivens" (Koch Stephen, 2005). "Ivens, who was filming The Spanish Earth, needed Hemingway as a screenwriter to replace John Dos Passos, who left the project when his friend José Robles was arrested and later executed" (Meyers Jeffrey, 1985). It can be said the incident made Dos Passos' think differently of the leftist republicansthat spread a rumor such as "Dos Passos was a coward for leaving Spain" (Koch Stephen, 2005). Bernice Kert clarifies about Martha, "she never catered to him the way other women did" (Kert Bernice, 1998).

Hemingway with his third wife in Madrid "wrote his only play, The Fifth Column, as the city was being bombarded. He returned to Key West for a few months, then back to Spain twice in 1938. He was present at the Battle of the Ebro, the last republican stand, and was among fellow British and American journalists who were some of the last to leave the battle as they crossed the river" (Meyers Jeffrey, 1985).

During their living, they functioned as literary partners both on articles for Colliers and on each other's manuscripts of books and stories in progress, including Hemingway's For Whom the Bell Tolls and Gellhorn's A Stricken Field, Heart of Another, and Liana.

Before his second marriage ended in 1940, Hemingway had published three story collections, Men without Women (1927), Winner Take Nothing (1933), and The Fifth Column and First Forty-Nine stories (1939); a bullfight treatise, Death in the Afternoon (1932); a nonfiction safari book, Green Hills of Africa (1934); and three novels, A Farewell to Arms (1929), To Have and Have Not (1937), and For Whom the Bell Tolls (1940).

Gellhorn established another perspective to that of Hemingway. While the latter played the leading role in his journalistic adventure, she recounted on the actors who died or survived. These metamorphoses in style would begin to go beyond the professional duel to intervene on the emotional level, and it would ruin the close bond. Both journalists and soldiers marched with the allies who had landed in Normandy in 1944. But on 25 November of the same year, in the Ritz Hotel in Paris where the liberation of that capital from the Nazi yoke was being celebrated, the relationship broke. Each went separate way; Hemingway with a correspondent Mary Welsh and Martha alone, because she was always faithful to him. Martha and Hemingway made a decision to cover the Spanish Civil War. She and Hemingway lived together off and on for four years, before marrying in December, 1940. Gellhorn resented her echoed fame as Hemingway's third wife, remarking that she did not intend of being a footnote in someone else's life. As a condition for yielding interviews, she was known to insist that Hemingway's name not be mentioned.

Gellhorn stimulated Hemingway to pen For Whom the Bell Tolls that he inscribed it in Cuba, Wyoming, and Sun Valley. It was Martha Gellhorn who convinced Ernest to come with her to observe the Spanish Civil War. It was she who 
saw the massacre of the D-Day beaches while he stayed safely on a ship. As a war reporter, she surpassed him; as a novelist, he put her in the shade and the opposition between them outlived their nine-year relationship, which ended in 1946.

His fourth and last wife was an American journalist, Mary Welsh. In 1948 they traveled to Europe. In 1951 Hemingway inscribed the rough copy of The Old Man and the Sea in two months, as it was one of the best works that he could pen during his life. "The Old Man and the Sea became a book of the month selection, made Hemingway an international celebrity, and won the Pulitzer Prize in May 1952, a month before he left for his second trip to Africa" (Desnoyers Megan Floyd).

After Hemingway's death Mary wrote her autobiography, How It Was that was printed in 1976 and might as well have been subtitled like The Importance of Being Ernest's Wife and stressed passages of affection and love. Of course here It referred to life with Hemingway.

As before mentioned Gertrude Stein, an American writer and expatriate, was one of the influential women on Hemingway. Meeting Stein with Hemingway was following a letter of recommendation Stein had received from Anderson in Paris in 1922. Hemingway soon understood that he could learn much from Stein. He was captivated by her "continuous present tense and her steady repetition of key phrases that created meanings larger than the words themselves and considered it useful to acquire those techniques" (Reynolds Michael S. Hemingway, 1999).

Stein accepted Hemingway and studies his first works as Hemingway's mentor; "Stein taught Hemingway about structure and composition with the example of cubist paintings as a guide and model for the organization of poetry and prose" (Leff Leonard et al. 1999). Having in mind that he could use his teachers, "Pound and Stein, for his career, he readily gave them his work for revision and accepted their advice and recommendations concerning style and publication" (Benson Jackson J. Hemingway, 1969). In journalism Hemingway had already developed his "declarative style which he refined with stylistic elements acquired from Stein" (Mellow James, 1974).

Edmund Wilson, one of Hemingway's critics and friends, states that "...Hemingway felt the genius of Gertrude Stein's Three Lives and had evidently been influenced by it" (Wilson Edmund, 1952). Wilson even says that "Ernest Hemingway, Gertrude Stein, and Sherwood Anderson formed a school of their own at the time. Each one of them used simple colloquial language, avoiding description and decorative adjectives. This, they thought, increases the quality of a story because the emotion evoked in the reader will be stronger; additionally they were of the opinion that a trait of an excellent writer is to convey emotion through omission. Hemingway, being by far the youngest of the three, learned much from his mentors. Nonetheless, he had developed a style of his own in which he hides the Steinian stylistic elements in a way that they enforce emotion but do not affect the intelligibility of his work" (Ibid).

In Stein exploration of the stream of consciousness, she attempted to convey the least easily-grasped area of consciousness the transitive. Her style was subsequently very difficult to follow. Hemingway, on the other hand, wrote decently about essential moments. He told: "I wrote some pretty good poems lately in Rhyme. We love Gertrude Stein" (Baker Carlos, 1981). "But their relationship slowly crumbled because both of them felt insulted by the other" (Sabin Stefana, 1996). After a few years, "Hemingway began to even deny the influence Stein had on him. Although Hemingway had not talked to Stein for years she is very present in novel For Whom the Toll Bells as a Spanish woman Pilar" (Brogan Jaqueline Vaught).

Jane Mason's role on Hemingway's life and works started with their met on an ocean liner. That time Hemingway married to Pauline who she was pregnant for second time. Jane Mason's husband was an American executive for Pan American Airways in Cuba... They became friends of Ernest and Pauline Hemingway, introducing the Hemingways into Cuban society. Hemingway and Jane created an affair as Hemingway took up protracted home at what would be his base in Havana for the next several years. In the following spring, as his second marriage kept on unraveling, Hemingway was in Havana for another extended stay, and once again Jane Mason was there.

Pauline used the reason of the annual visit of Hemingway's son Jack to come over from Key West as she took the boy to Havana to spend time with his father. But Hemingway made her feel undesirable and she soon went back to Key West alone. Hemingway also cheered rumors of an affair with Mason. He defined her as a damn fine girl, and used her as the model for the adulterous Margot Macomber in his The Short Happy Life of Francis Macomber short story.

19 year old Adriana Ivancich was other influential women on Hemingway. "The Platonic love affair inspired the novel Across the River and Into the Tree, published in 1950" (Meyers Jeffrey, 1985).

The Hemingways and Adriana were invited to a duck shooting party in Venice in 1948 was the first time that Hemingway met Adriana. That day, got a special day in Hemingway's life. He saw a young girl who got his muse for five years. About the meeting "It struck me like lightning, Hemingway confessed" (Meyers Jeffrey, 1985). "It was she, who made him write again, he said, the vein had dried out, around me there was only emptiness" (Kingge Jobst, 2011).

Adriana was glad according this belief also supposed that she had broken his author's block, and she was glad 
about it. "I had been so full of life and enthusiasm, that I transferred these to him, she wrote later: Hemingway told me that he fell ill while writing Across the River and into the Trees and that he had to lay the book aside, because he could not write any longer, but then he had got to know me and had felt how a new energy flowed over from me into him. Hemingway confirmed again later; you have given back to me the ability to write, and for that I always will be grateful to you. I was able to finish my book and have given a face to the heroine" (Kingge Jobst, 2011).

\section{Conclusion}

Five women played a strong role in different periods of Fitzgerald's life as sources of inspiration his works. Fitzgerald's works include several topics that are derived from experiences in his life Besides his mother and his wife, two other women, Ginevra King and Sheilah Graham, and Gertrude Stein played a major role in his life and deeply influenced on his fiction. His mother was the first influential women on him. Ginevra King was the love of his adolescence. This first romance was reflected in most of his stories such as his first novel, The Romantic Egoist, which was named This Side of Paradise afterward. Ginevra King served as inspiration for the characters Isabelle, Rosalind, and Eleanor, the three very fashionable girls in the novel. The Beautiful and the Damned is considered his most autobiographical novel. Beautiful Gloria, who loves spending a good time and wants to marry a rich man, is the reflection of both his earlier romance with Ginevra and his wife, Zelda. It can be noted his wife Zelda was the love of his life, and Sheilah Graham his reassure in his later years.

There were nine women who really had effected on Hemingway such as his mother, Agnes Von Kurowsky, his four wives, Gertrude Stein, Adriana Ivancich, and Jane Mason who had a great role in the life of the writer as sources of inspiration.

It can be said it's a myth that Hemingway hated women, but in reality, Hemingway has had attractive wives - one for each big book - and he has loved women enough to marry four of them whose impact can be seen in four of his major works. The impact of the women in his novels can be detected from different orientations. Hemingway inscribed Three Stories and Ten Poems that it summarized his love affair with Agnes,. Even eleven years later Hemingway was still remembering his love affair with Agnes. He wrote A Farwell to Arms which is based on him and Agnes. One has been promising from the critical appraisal view point which is the case of his first wife, Hadley. The other's role can be detected in the development of his financial status, a role which, for sure, can go to Pauline. Without her influence, may be, Hemingway could not write any more and create any other work of art. Hadley Richardson appears to be Ernest Hemingway's Paris wife. His second wife got as his Key West wife, Hemingway's third wife was known as his Spanish Civil War wife and Mary Welsh as his last wife.

Hadley was truly central to the rest of his life and career. Hemingway could not have come to be the author we know without his first wife's impact. The Sun Also Rises is critically acclaimed and commercially successful. A Farewell to Arms made Hemingway financially independent. Martha Gellhorn never stays of her love life with Ernest, although it constituted for him, as with all the writer's women, a very important period in his life. He dedicated For whom the Bell Tolls to her.

Gertrude Stein is very present in novel For Whom the Toll Bells as a Spanish woman Pilar. In Hemingway's The Short Happy Life of Francis Macomber, Jane Mason was as the model. The last and Platonic love affair with Adriana Ivancich caused Across the River and into the Tree.

\section{References}

Alabama Women's Hall of Fame. State of Alabama. (2012). http://encyclopediaof alabama.org/face/Article. 1120.

Baker, C. (1972). Hemingway: The Writer as Artist. Princeton. New Jersey. Princeton University Press. P. 15.

Baker, C. (1981). Ernest Hemingway: Selected Letters 1917-1961. Granada. Granada Publishing. P. 63.

Benson Jackson, J. (1969). Hemingway: The Writer's Art of Self-Defense. Minneapolis. Minnesota Paper Backs. P. 91.

Brogan Jaqueline Vaught. Parody or Parity: A Brief Note on Gertrude Stein and For Whom the Bell Tolls. http:// www.questia.com/ googleScholar.qst?docld.

Bruccoli Matthew, J. (2002). Fitzgerald Smith Scottie. Some Sort of Epic Grandeur: The Life of F. Scott Fitzgerald. University of South Carolina. P.3.

Bryant M. (1981). "F. Scott Fitzgerald," in Critical Survey of Long Fiction, Edited by Frank Magill. Salem Pres. pp.956.

Canterbery E.R. Birch, T.F. (2006). Scott Fitzgerald: Under the Influence. St. Paul. Paragon House. P.189.

Desnoyers Megan F. Ernest Hemingway: A Storyteller's Legacy. http:// www. jfklibrary. org/ Research/ The-Ernest-HemingwayCollecion/ Online-Resources/ Storytellers-Legacy.aspx?

Edmund W., Kurth, P. (1996). Zelda an Illustrated Life: The Private World of Zelda Fitzgerald. Edited by Eleanor Lanahan. Essays by 
Peter Kurth and Jane S. Livingston. New York. Harry Abrams. P.21.

Essay on The Women Who Influenced Francis Scott Key Fitzgerald's life. (1969). December 31. P.8. www.directessays.com/viewpaper/ 41832.html

F. Scott Fitzgerald and Zelda Fitzgerald Background. www.HumsanKinetics.com/ Dance.

Fitzgerald, F.S. (1964). The Crack-Up, With Other Uncollected Pieces, Note-Books and Unpublished Letters. Edited by Edmund Wilson. New York. New Directions. p. 87.

Gertrude Stein's letter to F. Scott Fitzgerald, reviewing The Great Gatsby. http://explore.noodle.org/post/55798184317.

Gertrude, S. (1961). An Autobiography of Alice B. Toklas. New York. Vintage Books. p. 218.

Kert, B. (1998). Hemingway's Women. New York. W.W. Norton. P. 287.

Kert, B. (1998). The Hemingway Women: Biography \& Autobiography. New York. W.W. Norton and Company. P. 23.

Kingge Jobst, C. (2011). Hemingway's Venetian Muse Adriana Ivancich: A contribution to the Biography of Ernest Hemingway. Berlin. Humboldt University Berlin. P. 20.

Koch S. (2005). The Breaking Point: Hemingway, Dos Passos and the Murder of Jose Robles. New York. Counterpoint. P. 87.

Leff Leonard, J. (1999). Hemingway and His Conspirators. Hollywood. Scribners and The Making of American Celebrity Culture. Lanham Rowman and Little Field Publisher. P. 6.

Martin Linda, W. (2007). Ernest Hemingway: A literary Life. New York. Palgrave. Macmillan. P. 57.

Mellow James, R. (1974). Charmed Circle: Gertrude Stein \& Company. London. Phaidon Press. P. 264.

Mellow James, R. (1992). Hemingway: A life Without Consequences. New York. Houghton Mifflin. P. 488.

Meyers, J. (1985). Hemingway: A Biography. London. Macmillan. P. 117.

Mizener Arthur. The Far Side of Paradise. Boston. Houghton Mifflin. 1965. P.11.

Mizener Arthur. The Far Side of Paradise. Boston. Houghton Mifflin. 1965. P.11.

Noden, M. (2003). Fitzgerald's First Love. Princeton Alumni. Volume 104. P. 21 http// books.google.com

Prigozy Ruth. The Cambridge Companion to F. Scott Fitzgerald. Cambridge University Pres. 2002. P.xv.

Reynolds Michael, S. (1999). Hemingway: The Paris Years. New York. W.W. Norton \& Company Inc. P. 37.

Ruland, R. Bradbury M. (1991). From Puritanism to Postmodernism: A History of American Literature. New York. Viking Penguin. P.251.

Sabin S. Gertrude S. (1996). Hamburg. Rowohlt Taschenbuchverlag. P. 2.

The women in F. Scott Fitzgerald's life and fiction. http://Suite101.com/article/

Wagner Martin. Linda. Zelda Sayre Fitzgerald: An American Woman's Life. New York. Palgrave Macmillan. 2004. P. 176).

Wilson, E. (1952). The Shores on Light. A Literary Chronicle of the Twenties and Thirties. New York. Farrar, Straus and Young. P. 119. Young Philip.(1973). Pamphlets on American Writers. Number 1: Ernest Hemingway. Minneapolis .University of Minnesota Press. P. 5. Zelda Fitzgerald and the French A. (2013). http://www.123HelpMe.com. 